\title{
Influence of Yeast $\beta$-Glucan on Cookies Sensory Characteristics and Bioactivities
}

\author{
Umar Bacha, ${ }^{1}$ Muhammad Nasir ${ }^{(D},{ }^{1}$ Sanaullah Iqbal, ${ }^{1}$ and Aftab Ahmad Anjum ${ }^{2}$ \\ ${ }^{1}$ Department of Food Science \& Human Nutrition, University of Veterinary and Animal Sciences, Lahore, Pakistan \\ ${ }^{2}$ Department of Microbiology, University of Veterinary and Animal Sciences, Lahore, Pakistan \\ Correspondence should be addressed to Muhammad Nasir; nasir@uvas.edu.pk
}

Received 3 August 2017; Accepted 21 January 2018; Published 12 March 2018

Academic Editor: Sevgi Kolaylı

Copyright (C) 2018 Umar Bacha et al. This is an open access article distributed under the Creative Commons Attribution License, which permits unrestricted use, distribution, and reproduction in any medium, provided the original work is properly cited.

$\beta$-Glucan is biologically active polysaccharide, ubiquitously found in many grains, bacteria, and fungi and much yeast. The aim of this study was to determine the effect of substituting wheat flour by 1,2 , and $4 \%$ yeast isolated $\beta$-glucan in cookies on the sensory acceptance, antioxidants, oxidative stability, and quality evaluation which were investigated. According to the results, cookies supplemented at $2 \%$ yeast $\beta$-glucan were proved satisfactory on sensory quality perspective. During the storage study it was found that cookies made with 2 and $4 \% \beta$-glucan have effectively $(p>0.05)$ kept the peroxide value (PV) within acceptable range, demonstrating the promising role of $\beta$-glucan in deterring oxidative. It is further noted that 2 or $4 \% \beta$-glucan incorporated cookies assimilated highest absorption spectra, suggesting the retardation in freshness losses, with having minimum microbial loads, showing microbiological safety. $\beta$-Glucan fortification in foods is technologically and economically feasible, suggesting that a significant prospect of $\beta$-glucan as low-cost food ingredient in formulating cookies at $2 \%$ offers exciting new use of $\beta$-glucan of yeast origin.

\section{Introduction}

Dietary fibers are polysaccharides of immense interest in nutrition. There is enough scientific evidence that demonstrated health benefits of dietary fibers. They can regulate physiological functions of the body and this aspect is validated in human, animals, and in vitro investigation. They can be useful in preventing and treating chronic diseases like diabetes, obesity, glycemic and cholesterol control, irritable bowel syndrome, and colon cancer $[1,2]$. Other health benefits associated with dietary fiber include, for example, weight management [2] and antioxidant [3]. Higher mortality and morbidity are reported in different population, partly, due to inadequate consumption of dietary fiber [4]. Epidemiological findings have suggested higher intake of dietary fiber to deter chronic diseases such as type 2 diabetes, various types of cancer, and cardiovascular diseases, to name a few [5]. A recent meta-analysis of observational findings has established inverse relation between dietary fiber intake and metabolic syndrome [6], suggesting positive effects of dietary fibers in prevention of chronic diseases.
One way to enhance dietary fiber intake is that it is necessary to fortify human foods with dietary fibers. Currently, dietary fibers are incorporated in flour products, including cookies, bread, noodles, milk, and meat derived foods [7]. Oat and barley (as a source of dietary fiber) are extensively studied in bakery products, cookies [3]. Frost et al. [8] reported barley flour (as a source of soluble $\beta$-glucan dietary fiber) in chocolate chip cookies. Similarly, Chappalwar et al. [9] reported cookies prepared from fortified oats and millet flour. These different studies on oat or barley fortified cookies reported better nutritional quality and physical attributes. However, studies on yeast $\beta$-glucan fortified cookies and their sensory evaluation are limited in the published data and so cookies with added yeast $\beta$-glucan are a new research in this regard.

Yeast $\beta$-glucan is more concentrated dietary fibers [10] with remarkable bioactivity and physicofunctional properties $[11,12]$ and its substitution in cookies is comparatively easy and technologically feasible. Moreover, yeast contains enough $\beta$-glucan (as dietary fiber) and $\beta$-glucan present in yeast is structurally different compared to $\beta$-glucan present in 
bacteria, oat, and barley. This variation in structure may offer extra health benefits since yeast $\beta$-glucan is larger in size and thus can make a difference in functionalities. The present work substituted 1,2 , and $4 \% \beta$-glucan in cookies and evaluated the following: (1) physicochemical and sensory characteristics of cookies; (2) storage stability; (3) the antioxidant capability; (4) quality evaluation through absorption spectra and microbiological safety.

\section{Materials and Methods}

2.1. Cookies Preparation. This study involves the preparation of cookies. All of the materials used for experimentation were purchased from a local market in Lahore, Pakistan. Based on some preliminary trials, wheat flour was fortified with $\beta$ glucan at 1.0, 2.0, and $4.0 \%$ levels along the control that does not have $\beta$-glucan. The following blends were made: control that contained $100 \%$ wheat flour; $1 \%, 2 \%$, and $4 \%$ treatments that contained $99 \mathrm{~g}, 98 \mathrm{~g}$, and $96 \mathrm{~g}$ wheat flour and $1 \mathrm{~g}, 2 \mathrm{~g}$, and $4 \mathrm{~g}$ of $\beta$-glucan, respectively.

The cookies were prepared according to the procedure [13]. $\beta$-Glucan was added according to the quantity of wheat flour. Cookies were prepared according to the following composition: sugar $=100 \mathrm{~g}$, flour $=200 \mathrm{~g}$, and shortening (vegetable ghee) $=100 \mathrm{~g}$, additionally, one egg was added, baking powder $=3.0 \mathrm{~g}$, and added water as per requirement $(10-25 \mathrm{~mL})$. This was followed by mixing the ingredients (Model N-50, Hobart Corp., Troy, Ohio, USA). Further, shortening was processed so that cream was formed after the sugar mixing; then eggs were added. The process was considered complete when foaming was formed. To this foam/mixture add flour and baking powder followed by mixing to a homogeneous appearance. After this stage, water was added and the batter made, with having optimum consistency. Through the help of a cookie cutter batter was cut and the cookies were kept on baking trays. Uniform distance was maintained between cookies followed by baking the cookies at $425^{\circ} \mathrm{F}$ in the baking oven, $12-15 \mathrm{~min}$. After this time, it was ensured that cookies got at room temperature. Then cookies were packed in polythene bags for further assessments.

2.2. Proximate Composition. Proximate chemical compositions such as dry matter (DM), crude protein (CP), ether extract (EE), and ash content were determined by following their respective procedures [14].

2.3. Sensory Evaluation. Sensory evaluations of the cookies were carried out according to the procedure of Meilgaard et al. [15]. Experts in sensory evaluation were requested through e-mails, fliers, and personal contacts and consent forms were signed. Further, judges were trained in the sensory evaluation of cookies, and then the judges were requested to complete an additional questionnaire form. For the sensory analyses cookies were prepared $24 \mathrm{hrs}$ prior to evaluation. Trays with having white background were used for presenting samples for the analyses. Moreover, panelists were given performa having written instruction of sensory attributes, at room temperature, Department of Food Science and Human Nutrition, University of Veterinary and Animal Sciences, Lahore, Pakistan. Finally, samples presented for analyses were accessible in random order and judges were told to rate their preference by marking a cross on the $15 \mathrm{~cm}$ - unconstructed line for all the sensory indices. Data obtained from sensory evaluation scored by the panelist was then changed to numeric values through metric scale. The information regarding metric scale and performa is given in our previous paper [16].

2.4. Antioxidants Evaluation. The following steps were taken: exactly $10 \mathrm{~g}$ of sample (grounded into flour) was added to $100 \mathrm{~mL}$ distilled water followed by shaking for an hour. This was followed by the filtration using Whatman paper. The residue left on filter paper was mixed with another $100 \mathrm{~mL}$ ethanol (96\%) and was shaken for the specified time, followed by filtration. This procedure was repeated again and threetime filtrate obtained was mixed and vacuum-dried. The solution was prepared by mixing the dried extract $(10 \mathrm{mg})$ in $1.0 \mathrm{~mL}$ of distilled water and then $0.1 \mathrm{~mL}$ of this solution was used for the following experiment.

2.5. Total Phenolic Content (TPC) Estimation. Exactly $0.1 \mathrm{~mL}$ of the solution (as shown above) was mixed with distilled water and followed by mixing with $0.5 \mathrm{~mL}$ of FolinCiocalteau's reagent $(10 \% \mathrm{v} / \mathrm{v})$ and sodium carbonate solution $(0.4 \mathrm{~mL}, 7.5 \% \mathrm{w} / \mathrm{v})$. The reaction mixture was kept continued for almost $90 \mathrm{~min}$. This was followed by reading the absorbance at $750 \mathrm{~nm}$ [17].

2.6. Estimation of Ferric Reducing Antioxidant Power (FRAP). The estimation of FRAP was carried out according to the procedures described in an earlier study [18]. Almost $1.0 \mathrm{~mL}$ sample was taken in a test tube. Then add the phosphate buffer having $\mathrm{pH} 6$ so that the final volume in the test tube was adjusted to $3.5 \mathrm{~mL}$. Later, the volume in the test tube was further increased to $6 \mathrm{~mL}$ by the addition of potassium ferricyanide. The test tubes were kept in a water bath at $50^{\circ} \mathrm{C}$ for $30 \mathrm{~min}$. After the incubation time, volume in the test tube was further increased to $8.5 \mathrm{~mL}$ by adding TCA and then centrifugation. About $2.5 \mathrm{~mL}$ of supernatant was taken from the centrifuge tube and transferred to an empty test tube and then charged with $0.5 \mathrm{~mL}$ ferric chloride. The chromophore formed was read at $593 \mathrm{~nm}$. The standard used in this experiment was Trolox and the data was reported as $\mathrm{mg}$ Trolox equivalent/g of sample.

2.7. Iron Binding Capacity. The assay was performed according to the procedure [19] with some alteration. Briefly in a test tube $1.0 \mathrm{~mL}$ of sample was taken. After this $\mathrm{FeCl}_{2}(50 \mu \mathrm{L})$ was added to the same test tube and then $100 \mu \mathrm{L}$ ferrozine was added. The test tubes were kept standing for $10 \mathrm{~min}$ at room temperature. This was followed by reading their absorbance at $562 \mathrm{~nm}$ using a spectrophotometer. The standard EDTA was similarly treated.

2.8. Oxidative Stability Study (Peroxide Value). The storage stability was determined in terms of peroxide value (PV). This 
value was measured according to the procedure [20] during 0 days, 15 days, and 30 days.

2.9. Microbiological Quality of $\beta$-Glucan Incorporated Cookies. Control wheat flour and $\beta$-glucan fortified cookies were made into powder. From each type of sample, a representative $1.0 \mathrm{~g}$ power was taken into a test tube. This was followed by making $10 \mathrm{~mL}$ final volume in the test tube using sterile distilled water and centrifugation. The bottom sample about $4-5 \mathrm{~mL}$ was subject to serial dilution (10-fold) and was subsequently streaked on their respective media for the analysis of total viable count and fungal load according to the procedure given [21].

2.10. In Vitro Glucose Release Study. Wheat flour and $\beta$ glucan added flour were evaluated for their in vitro glycemic response due to the fact that glycemic response of the food is linked with obesity and type 2 diabetes [22]. The procedure is adopted as indicated by [23].

2.11. Physical Analysis of the Cookies. Parameters like thickness, width, and spread factor were determined according to methods [13]. For measuring the diameter, six cookies were placed horizontally (edge to edge). Duplicate reading was obtained by rotating the cookies at $90^{\circ}$ angles and this process was repeated for one more time in order to get triplicate data. Regarding the thickness, six cookies were placed on one another. The data obtained from this experiment are divided by 6 , resulting in cookie thickness for a single cookie. The following formula was used for calculating spread factor (SF):

$$
\mathrm{SF}=D \times \mathrm{CF} \times \frac{10}{T},
$$

where $D$ is diameter; $T$ is thickness; correction factor (CF), factor at constant atmospheric pressure, is 1.0 in this case.

2.12. Absorption Spectroscopy. Spectral data were obtained using an absorption spectrometer. Samples were scanned between 400 and $700 \mathrm{~nm}$ and the results were expressed as $(1 / R)$, according to the procedures [24].

2.13. Functional Properties. Parameters, for example, water, oil absorption capacities [25], and swelling power, were determined accordingly.

2.14. Statistical Analyses. Data of the experiments was analyzed using analysis of variance technique. Costat-2003 software was used for analysis of the data, applying completely randomized design [26], and, where applicable, 2-factor ANOVA was used to analyze the data. Means were separated for statistical comparison with the Duncan Multiple Range Test [27]. The level of significance was defined as $p \leq 0.05$.

\section{Results and Discussion}

3.1. Proximate Composition. Table 1 shows the results of the proximate composition of control and flour fortified with $\beta$-glucan. Protein, crude fiber, ash, and fat concentration were found to be significantly affected $(p \leq 0.05)$ by the addition of $\beta$-glucan. The DM of the flours is presented in Table 1. Flour blend having $4 \% \beta$-glucan retained highest crude proteins and crude fat as shown in Table 1; however, crude fiber level remained the same in 2 and $4 \% \beta$-glucan fortified flour. The earlier findings reported more protein concentration (11\%) in the wheat flour [28] than the presently investigated value of protein. This difference might be due to the type of wheat flour, processing method (drying), and other conditions. Girma et al. [29] reported that drying method (cassava) has impact on chemical composition.

3.2. Sensory Analyses of Cookies. The sensory tests are predictive of quality of food, as sensory screening helps attracting consumers [30], increase profitability, and build consumer confidence. In this study, $\beta$-glucan addition has profoundly affected $(p=0.00)$ color, flavor, taste, and overall quality of the cookies (Table 2). Color attribute was rated high in case of control cookies versus $\beta$-glucan incorporated cookies. The deterioration of color may be attributed to absorption of moisture from surrounding and due to Maillard reaction since $\beta$-glucan fortified cookies have higher amounts of protein which could have reacted with sugar present in the cookies and thus resulted in color variation. Similar finding is reported previously [31].

The flavor and taste ratings ( $p \leq 0.05$ ) were negatively affected at $4 \% \beta$-glucan incorporation but not at the lower rate of $\beta$-glucan addition. Similarly, overall quality ratings were preferred more in control, 1 and $2 \% \beta$-glucan substituted cookies versus those fortified with $4 \% \beta$-glucan cookies. The flavor scores (Table 2) were plotted versus overall quality scores and their results indicated $\left(R^{2}=0.752\right)$ intermediate correlation, suggesting that somehow the flavor has affected the overall quality [32].

As indicated in Table 2, $\beta$-glucan substitutions at $4 \%$ in cookies were not liked by the sensory panelist (due to off-taste and flavor). Kerckhoffs et al. [33] reported that color and taste score are changed in response to the fiber source. $\beta$-Glucan at higher level of fortification resulted in off-taste and thus at $4 \%$ supplementation into the cookies was not liked by the sensory panelist. Siwela et al. [34] reported that poor taste can negatively influence acceptability of wheat finger millet based cookies. It is therefore important to improve these two sensory parameters in the future studies. Market analysis indicated that barley ( $\beta$-glucan) was substituted in barley rusks $[35,36]$ at $40 \%$ barley flour into bread. Those authors reported the satisfactory response from the consumers. This suggests that yeast $\beta$-glucan would be an additional opportunity for the food industry to fortify foods that would have far more medical benefits and functional properties. Overall quality of $2 \% \beta$-glucan incorporated cookies suggesting the potential of $2 \% \beta$-glucan made cookies for human consumption. The market values of oat and barley $\beta$-glucan based foods are already tested in various formulations $[37,38]$ with commercial success. Therefore, there is great potential for the commercialization of yeast $\beta$-glucan fortified products having better functional attributes. 
TABLE 1: Proximate composition of flour with added $\beta$-glucan compared to the control flour.

\begin{tabular}{lccccc}
\hline Product & DM (\%) & CP (\%) & Crude fiber & EE (\%) & Ash (\%) \\
\hline Control flour & $86.166 \pm 1.590^{\mathrm{a}}$ & $5.533 \pm 0.124^{\mathrm{b}}$ & $2.6 \pm 0.489^{\mathrm{b}}$ & $1.3 \pm 0.163^{\mathrm{c}}$ & $0.63 \pm 0.049^{\mathrm{b}}$ \\
\% flour & $88.4 \pm 1.593^{\mathrm{a}}$ & $4.546 \pm 0.263^{\mathrm{c}}$ & $3.033 \pm 0.169^{\mathrm{b}}$ & $2.4 \pm 0.081^{\mathrm{b}}$ & $1.166 \pm 0.124^{\mathrm{a}}$ \\
$2 \%$ flour & $87.5 \pm 0.898^{\mathrm{a}}$ & $5.353 \pm 0.055^{\mathrm{b}}$ & $3.966 \pm 0.418^{\mathrm{a}}$ & $2.333 \pm 0.124^{\mathrm{b}}$ & $0.8 \pm 0.081^{\mathrm{b}}$ \\
$4 \%$ flour & $85.633 \pm 3.681^{\mathrm{a}}$ & $7.046 \pm 0.041^{\mathrm{a}}$ & $4.766 \pm 0.205^{\mathrm{a}}$ & $8.366 \pm 0.262^{\mathrm{a}}$ & $0.623 \pm 0.012^{\mathrm{b}}$ \\
\hline
\end{tabular}

Different letters in a column present significant $(p \leq 0.05)$ effect, according to 1-factor ANOVA, and the differences between the means were evaluated by DMR test. The level of significance was $\alpha=0.05$. Triplicate results are presented $(n=3)$.

TABLE 2: Sensory evaluation of cookies with added $\beta$-glucan compared to the control cookies.

\begin{tabular}{lccccc}
\hline Product & Color & Flavor & Taste & Crispiness & Overall quality \\
\hline Control cookies & $10.730 \pm 1.247^{\mathrm{a}}$ & $11.333 \pm 0.945^{\mathrm{a}}$ & $11.2 \pm 1.058^{\mathrm{a}}$ & $11.1 \pm 1.352^{\mathrm{a}}$ & $12.2 \pm 0.588^{\mathrm{a}}$ \\
$1 \%$ cookies & $10.2 \pm 0.449^{\mathrm{b}}$ & $11.3 \pm 1.336^{\mathrm{a}}$ & $10.733 \pm 0.329^{\mathrm{a}}$ & $10.8 \pm 1.296^{\mathrm{a}}$ & $10.866 \pm 0.659^{\mathrm{a}}$ \\
$2 \%$ cookies & $8.846 \pm 0.610^{\mathrm{c}}$ & $11.933 \pm 0.339^{\mathrm{a}}$ & $12.033 \pm 0.946^{\mathrm{a}}$ & $10.1 \pm 0.216^{\mathrm{a}}$ & $11.866 \pm 0.997^{\mathrm{a}}$ \\
$4 \%$ cookies & $5.561 \pm 0.919^{\mathrm{d}}$ & $8.4 \pm 1.349^{\mathrm{b}}$ & $8.566 \pm 1.096^{\mathrm{b}}$ & $10.9 \pm 0.294^{\mathrm{a}}$ & $8.403 \pm 0.922^{\mathrm{b}}$ \\
\hline
\end{tabular}

Different letters in a column present significant $(p \leq 0.05)$ effect, according to 1-factor ANOVA, and the differences between the means were evaluated by DMR test. The level of significance was $\alpha=0.05$. Results are presented $(n=30)$.

TABLE 3: Antioxidant properties of cookies made with $\beta$-glucan compared to the control cookies and control flour.

\begin{tabular}{lccr}
\hline Product & TPC & FRAP & IBC \\
\hline Control flour & $4.29 \pm 0.767^{\mathrm{b}}$ & $0.643 \pm 0.093^{\mathrm{a}}$ & $0.816 \pm 0.062^{\mathrm{b}}$ \\
Control cookies & $6.126 \pm 0.467^{\mathrm{a}}$ & $0.7 \pm 0.081^{\mathrm{a}}$ & $1.4 \pm 0.163^{\mathrm{a}}$ \\
$1 \%$ cookies & $6.176 \pm 0.365^{\mathrm{a}}$ & $0.666 \pm 0.124^{\mathrm{a}}$ & $1.333 \pm 0.169^{\mathrm{a}}$ \\
$2 \%$ cookies & $6.226 \pm 0.368^{\mathrm{a}}$ & $0.833 \pm 0.169^{\mathrm{a}}$ & $1.533 \pm 0.124^{\mathrm{a}}$ \\
$4 \%$ cookies & $6.25 \pm 0.261^{\mathrm{a}}$ & $0.733 \pm 0.124^{\mathrm{a}}$ & $1.6 \pm 0.081^{\mathrm{a}}$ \\
\hline
\end{tabular}

$\mathrm{TPC}=$ total phenolic contents (mg GAE/g); FRAP = ferric reducing antioxidant power (TE mg/g); IBC = iron binding capacity (mg EDTA/g). The results are presented in the form of mean \pm SD of replicates: $n=3$. Different letters in a column present significant $(p \leq 0.05)$ effect, according to 1-factor ANOVA, and the differences between the means were evaluated by DMR test. The level of significance was $\alpha=0.05$.

3.3. Effect of $\beta$-Glucan Addition on Antioxidants. Results regarding the antioxidants capabilities of different cookies and flour are presented in Table 3. According the results, total phenolic contents (TPC) and iron binding capacity (IBC) of cookies were affected ( $p=0.0082, p=0.0009)$ in response to $\beta$-glucan addition while ferric reducing antioxidant power, FRAP, was not affected ( $p=0.5918$ ). To understand the effect of baking, control flour and cookies were evaluated for their antioxidants along other treatment groups. Interestingly, control flour has significantly lowest TPC values compared to control cookies and cookies made with $\beta$-glucan, indicating the positive effect of baking over antioxidant levels. Similar finding has also been documented earlier [34] in case of finger millet cookies where the authors stated that thermal treatment produced structural changes/intermediate structures responsible for enhanced bioactivities. The effects of 1,2 , and $4 \% \beta$-glucan on TPC or IBC in cookies were similar among and compared to control cookies (Table 3). Further, cookies have demonstrated similar trends in IBC as well. In general, 2 and $4 \% \beta$-glucan incorporation increased the efficacy of the $\beta$-glucan substituted cookies. This might be due to the structural stability of wheat flour components after the addition of dietary fiber ( $\beta$-glucan). Earlier findings suggested the effect of fibrous fibers on structural modification of wheat flour proteins [39]. Also, high baking temperature produced caramelization intermediates which are associated with antioxidant activities [40].

3.4. Effect of $\beta$-Glucan on Storage Stability. Analysis of variance ( 2 factors) was used to evaluate the effect of storage time and $\beta$-glucan levels on the peroxide value (Figure 1), PV. Storage time and $\beta$-glucan level have affected $(p<0.0001) \mathrm{PV}$ of cookies. The interaction study $(\beta$-glucan levels and storage time) showed strong association $(p \leq 0.0003)$. Cookies made with $2 \%$ and $4 \% \beta$-glucan were proved effective in keeping the PV values within the acceptable range $(p \leq 0.05)$ versus the control cookies that increased after 15 days and 30 days. These findings are in collaboration with Haghshenas et al. [41] who reported that control and carboxymethyl cellulose treated shrimp nugget had more lipid oxidation than shrimp nugget treated with $\beta$-glucan. Cookies incorporated with $1 \% \beta$-glucan showed no change in PV till 15 days $(p>$ $0.05)$ but then exhibited significantly $(p<0.001)$ higher PV after 30 days. In general, the effect of $2 \%$ or $4 \% \beta$ glucan addition is significant, as they exhibited protective ability against oxidative deterioration. This might be due the protective action of $\beta$-glucan on wheat flour antioxidants. Shakerardekani et al. [42] reported that antioxidants are important for reduction in autoxidation and destability of food products. 
TABLE 4: Microbiological qualities of control wheat flour and $\beta$ glucan incorporated cookies.

\begin{tabular}{lcc}
\hline Treatment & TVC & ${ }^{*}$ Fungus \\
\hline Wheat flour & $1.306 \pm 0.077$ & $1.243 \pm 0.054$ \\
$1 \%$ cookies & $1.313 \pm 0.083$ & $1.343 \pm 0.041$ \\
$2 \%$ cookies & $1.303 \pm 0.057$ & $1.343 \pm 0.012$ \\
$4 \%$ cookies & $1.293 \pm 0.066$ & $1.29 \pm 0.0432$ \\
\hline
\end{tabular}

The results are presented in the form of mean \pm SD of replicates: $n=3$; the mean $\pm \mathrm{SD}$ is followed by $10^{1} \mathrm{cfu} / \mathrm{g}$; means with different letter in a column present significant $(p \leq 0.05)$ effect, according to 1-factor ANOVA, and the differences between the means were evaluated by DMR test. The level of significance was $\alpha=0.05 .{ }^{*}$ Fungus $=$ yeast $/$ moulds; $\mathrm{WF}=$ wheat flour TVC $=$ total viable count.

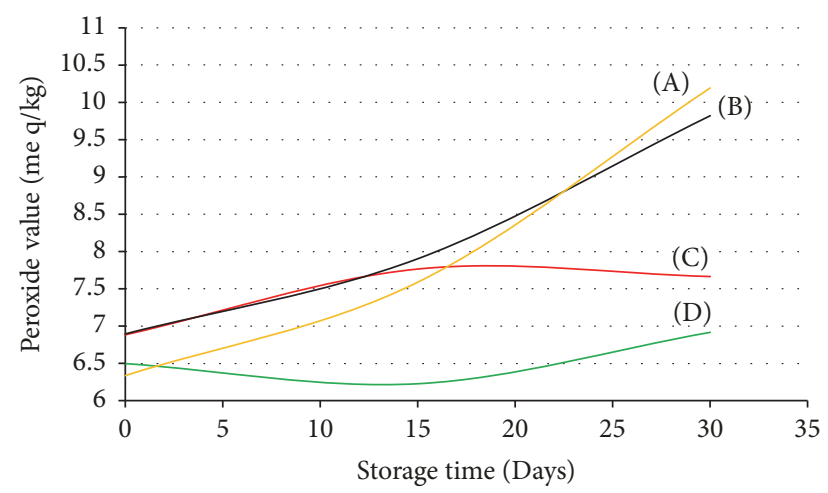

Figure 1: Peroxide value of cookies versus storage time (days). Control cookies (A); $1 \% \beta$-glucan made cookies (B); $4 \% \beta$-glucan made cookies (C); $2 \% \beta$-glucan made cookies (D).

\subsection{Microbiological Quality of $\beta$-Glucan Incorporated Cookies.} Physical and chemical deterioration are continually happening and a challenging task in food industry. Bakery products are vulnerable to such natural process. Microbial spoilage, in addition to other, is the most occurring process that seriously affects safety of the food product. These adverse effects limit the shelf life of the bakery products. There is often the threat of bacteria, yeast, and molds in bakery products [43]. The results regarding the microbial quality of cookies are given (Table 4). The results showed no statistical difference $(p \geq 0.05)$ between different treatments for the total viable count (TV) and fungus (yeast/molds). The total viable count is intended to describe the total number of living microorganisms in a product intended for the human consumption. Mossel and Van Netten [44] reported that there should be no more than $10^{3} \mathrm{cfu} / \mathrm{g}$ microbial cells in food products (at $35^{\circ} \mathrm{C}$ ) that do not require further cooking.

3.6. In Vitro Glycemic Index Study. Wheat flour (100\%) and $\beta$-glucan added flour were evaluated for their in vitro glycemic response (Figure 2). Since the glycemic response of food could relate the food to chronic diseases, that is, obesity and type 2 diabetes, estimating the glycemic response of food is important to understand. Food samples were digested using HCL and enzymes and their effect on sugar released were determined over time. According to the results, wheat flour

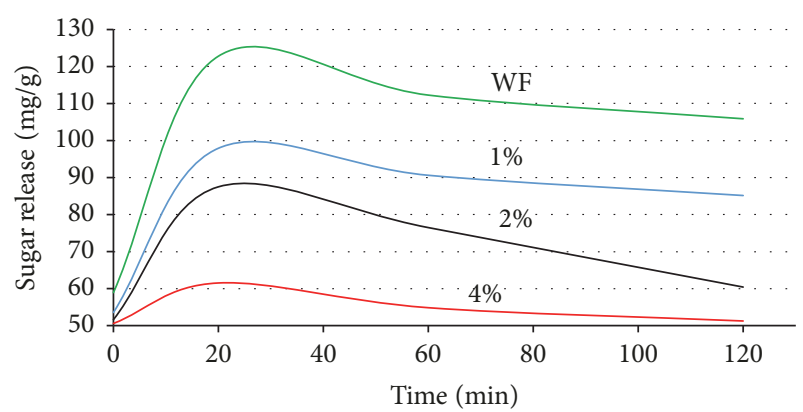

FIgURE 2: In vitro glycemic response study of control and $\beta$-glucan added flour. $\mathrm{WF}=$ wheat flour; $1 \%=\beta$-glucan added at $1 \%$ level to wheat flour; $2 \%=\beta$-glucan added at $2 \%$ level to wheat flour; $4 \%=$ $\beta$-glucan added at $4 \%$ level to wheat flour.

released significantly higher $(p \leq 0.05)$ sugar versus $\beta$ glucan added flour. Furthermore, the effect of 2 and $4 \% \beta$ glucan added flour was better than wheat flour added with $1 \% \beta$-glucan. Jeng et al. [45] evaluated the inhibitory effect of sweet potato leaf extract on glucose release from native starch. The author(s) reported that due to the presences of bioactive components in sweet potato leaves it was possible to slow down glucose release during in vitro digestion. These results are highly encouraging as $\beta$-glucan added flour mix has retarded the digestion of sugar and therefore their utilization in foods could help in glucose control or diabetes management.

3.7. Physical Analyses of Cookies. The molecular size of $\beta$-glucan varied across different sources. Oat, barley, and bacteria represent low molecular size $\beta$-glucan versus yeast $\beta$-glucan, which is comparatively large. This variation in molecular size results in different physiological and rheological characteristics. The physical analysis revealed that the diameter and thickness increased with the incorporation of $\beta$-glucan. Cookies fortified with $2 \% \beta$-glucan exhibited high diameter (Table 5) and thickness compared with others (Table 5) but there was no change in the relative spread factor of the control cookies ( $p=0.105)$ versus other $\beta$-glucan fortified cookies. These findings are in collaboration with the previous study [46] who reported that cookies diameter and thickness increase with the addition of oat-flour (as source of $\beta$-glucan) while spread factor remains statistically similar. Moreover, the yeast $\beta$-glucan possesses huge hydrophobic groups (FTIR data) and was difficult to dissolve in water. These findings suggest that $\beta$-glucan incorporated cookies should not show big variation in the spread factor, unless the prior processing of $\beta$-glucan in an oxidizing medium, which affect the viscosity.

3.8. Near-Infrared Spectroscopy: Spectra Measurements. Absorption spectroscopy is largely used to determine the quality attributes of food. Also, it gives broad picture regarding the physical and chemical nature of foods; for example, Kamboj et al. [47] quantified components of the chickpea flour by using Near-Infrared Spectrometer. The technique involves the differences between the spectral lines/ fingerprints of fresh and aged food samples. Abu-Ghoush 
TABLE 5: Physical characteristics of cookies with added $\beta$-glucan compared to the control cookies.

\begin{tabular}{lccr}
\hline Product & Diameter $(\mathrm{cm})$ & Thickness $(\mathrm{cm})$ & Spread factor \\
\hline Control cookies & $5.733 \pm 0.169^{\mathrm{d}}$ & $0.955 \pm 0.028^{\mathrm{d}}$ & $60.003 \pm 0.001$ \\
$1 \%$ cookies & $6.266 \pm 0.04714^{\mathrm{c}}$ & $1.044 \pm 0.008^{\mathrm{c}}$ & $60.00 \pm 0.000$ \\
$2 \%$ cookies & $7.5 \pm 0.163^{\mathrm{a}}$ & $1.249 \pm 0.027^{\mathrm{a}}$ & $60.001 \pm 0.001$ \\
$4 \%$ cookies & $7.033 \pm 0.169^{\mathrm{b}}$ & $1.172 \pm 0.028^{\mathrm{b}}$ & $60.001 \pm 0.000$ \\
\hline
\end{tabular}

Different letters in a column present significant $(p \leq 0.05)$ effect, according to 1-factor ANOVA, and the differences between the means were evaluated by DMR test. The level of significance were $\alpha=0.05$.

TABLE 6: Functional properties of flour with added $\beta$-glucan compared to the control flour.

\begin{tabular}{lccc}
\hline Product & WHC (\%) & OHC (\%) & Swelling (\%) \\
\hline Control flour & $139 \pm 3.681^{\mathrm{c}}$ & $134 \pm 2.86^{\mathrm{a}}$ & $3.033 \pm 0.416^{\mathrm{c}}$ \\
$1 \%$ flour & $147 \pm 4.109^{\mathrm{c}}$ & $129 \pm 3.299^{\mathrm{a}}$ & $3.366 \pm 0.124^{\mathrm{bc}}$ \\
$2 \%$ flour & $161 \pm 4.642^{\mathrm{b}}$ & $136 \pm 3.559^{\mathrm{a}}$ & $3.7 \pm 0.1^{\mathrm{ab}}$ \\
$4 \%$ flour & $174 \pm 3.265^{\mathrm{a}}$ & $136.3 \pm 3.299^{\mathrm{a}}$ & $4.166 \pm 0.262^{\mathrm{a}}$ \\
\hline
\end{tabular}

WHC = water holding capacity; OHC $=$ Oil holding capacity; results are presented in the form of mean \pm SD of replicates: $n=3$; means with different letter in a column present significant $(p \leq 0.05)$ effect, according to 1-factor ANOVA, and the differences between the means were evaluated by DMR test. The level of significance was $\alpha=0.05$.

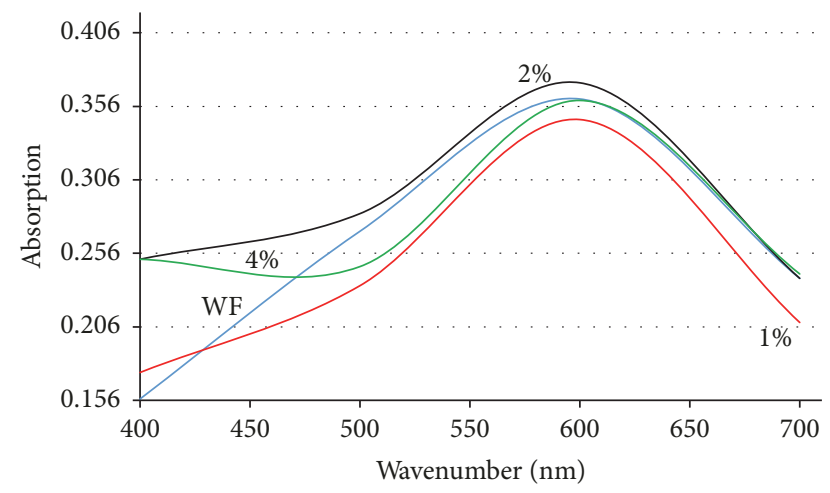

FigURE 3: Spectral absorption of cookies after 2 days of storage. $\mathrm{WF}=$ wheat flour; $1 \%=\beta$-glucan added at $1 \%$ level to wheat flour cookies; $2 \%=\beta$-glucan added at $2 \%$ level to wheat flour cookies; $4 \%$ $=\beta$-glucan added at $4 \%$ level to wheat flour cookies.

et al. [24] have used the absorption spectroscopy for measuring freshness loss in the bread samples. According to the results, absorbance spectra for the control cookies (wheat flour) and $1 \% \beta$-glucan fortified cookies were lower than the absorbance for the cookies made with 2 or $4 \% \beta$-glucan, suggesting that the $\beta$-glucan incorporation in the cookies at 2 or $4 \%$ reduces freshness losses versus control cookies or cookies made with $1 \% \beta$-glucan (Figure 3 ). Present findings are supported by Havrlentová et al. [48] who analyzed bread and ketchup (having $\beta$-D-glucan hydrogels) prepared with wheat, oat, barley, and rye. They reported bread freshness during the storage which was possible due to the addition of $\beta$-D-glucan barley and rye.

3.9. Functional Properties. Control flour and flour with added $\beta$-glucan was analyzed for their functional properties (Table 6). Results indicated that significant differences existed in the case of water holding (WHC) and swelling capacity of the control and $\beta$-glucan fortified flour $(p<0.0001$, $p<0.0059)$, respectively. Regarding WHC, $2 \%$ and $4 \% \beta$ glucan added flour showed an increase in WHC and swelling power (Table 6) compared with others. Since $4 \% \beta$-glucan added flour has the highest protein concentration, this can be the reason for holding higher amount of water. This implies that the flour blend with high-protein will likely absorb more water and oil versus other flour blends [49]. Furthermore, at high temperature (during heating) the molecule moves apart, creating a space between molecules and thus, due to this effect the $4 \% \beta$-glucan added flour makes the $\beta$-glucan molecules assimilate water and swell up. The phenomena are also reported elsewhere [50]. Moreover, Chandra et al. [51] reported that flour with better water or oil holding capacity plays important role in innovative foods including bakery products and sausage, to name few. Another reason for higher water and oil holding capacity of the fortified flour can be attributed to structural changes that may happen in response to $\beta$-glucan addition, for example, $\beta$-glucan interaction with proteins of the wheat flour. As stated by Chandra et al. [51] flour with high water holding capacity actually has better hydrophilic constituents (protein and polysaccharide have hydrophilic and hydrophobic properties). Due to hydrophilic nature of composite flour there are better chances of interact between hydrophilic constituents and water.

\section{Conclusions}

The results of the present investigations have validated the prospective usage of yeast $\beta$-glucan in bakery items. Our results showed that $2 \%$ of $\beta$-glucan could be added to wheat flour without producing a noteworthy adverse impact on the sensory acceptability of the cookies. Substituting $\beta$-glucan at this level might be of consumer's interest because of the improved values of antioxidants and sensorial attributes.

$\beta$-Glucan incorporated cookies, assimilated highest absorption spectra, suggesting the retardation in freshness losses. $\beta$-Glucan containing flour versus control wheat 
flour has significant variation in glucose release; at higher $\beta$-glucan concentration the rate of glucose release was lowest, thus establishing the fact that $\beta$-glucan could be the future nutraceutical supplement for diabetes control. Cookies had minimum microbial loads and with enhanced oxidative stability, suggesting microbiological quality and longer shelf life. The $\beta$-glucan fortification in foods is technologically and economically feasible and our investigation established a significant prospect of $\beta$-glucan, as low-cost food ingredient, in formulating cookies at $2 \%$, offers exciting new use of $\beta$-glucan of yeast origin.

\section{Additional Points}

Novelty Statement. Yeast $\beta$-glucan is a complex dietary fiber with strong immune enhancing, cholesterol lowering, and glucose control ability but this $\beta$-glucan is rarely fortified in bakery products such as cookies. Our results show that yeast $\beta$-glucan fortified cookies exhibit superior sensory qualities and antioxidants capabilities. Moreover, $\beta$-glucan fortified cookies kept the peroxide and glucose level within acceptable range, suggesting the futuristic role of $\beta$-glucan fortified products in deterring oxidative and diabetic damage. This suggests that $\beta$-glucan can be used as low-cost food ingredient in bakery products formulation.

\section{Conflicts of Interest}

The authors declare that there are no conflicts of interest regarding the publication of this paper.

\section{Acknowledgments}

The authors are grateful to Higher Education Commission (HEC), Pakistan, for financial support during their research work.

\section{References}

[1] Y. O. Li and A. R. Komarek, "Dietary fibre basics: Health, nutrition, analysis, and applications," Food Quality and Safety, vol. 1, no. 1, pp. 47-59, 2017.

[2] M. El-Salhy, S. O. Ystad, T. Mazzawi, and D. Gundersen, "Dietary fiber in irritable bowel syndrome (Review)," International Journal of Molecular Medicine, vol. 40, no. 3, pp. 607-613, 2017.

[3] W. Han, S. Ma, L. Li, X.-X. Wang, and X.-L. Zheng, "Application and development prospects of dietary fibers in flour products," Journal of Chemistry, vol. 2017, Article ID 2163218, 8 pages, 2017.

[4] E. S. Eshak, H. Iso, C. Date et al., "Dietary fiber intake is associated with reduced risk of mortality from cardiovascular disease among Japanese men and women," Journal of Nutrition, vol. 140, no. 8, pp. 1445-1453, 2010.

[5] Y.-Y. Yang, S. Ma, X.-X. Wang, and X.-L. Zheng, "Modification and Application of Dietary Fiber in Foods," Journal of Chemistry, vol. 2017, Article ID 9340427, 2017.

[6] B. Wei, Y. Liu, X. Lin, Y. Fang, J. Cui, and J. Wan, "Dietary fiber intake and risk of metabolic syndrome: A meta-analysis of observational studies," Clinical Nutrition, 2017.
[7] D. Dhingra, M. Michael, H. Rajput, and R. T. Patil, "Dietary fibre in foods: a review," Journal of Food Science and Technology, vol. 49, no. 3, pp. 255-266, 2012.

[8] D. J. Frost, K. Adhikari, and D. S. Lewis, "Effect of barley flour on the physical and sensory characteristics of chocolate chip cookies," Journal of Food Science and Technology, vol. 48, no. 5, pp. 569-576, 2011.

[9] V. M. Chappalwar, D. Peter, H. Bobde, and S. M. John, "Quality characteristics of cookies prepared from oats and finger millet based composite flour," Engineering Science and Technology: An International Journal, vol. 3, pp. 667-683, 2013.

[10] S. Bell, V. M. Goldman, B. R. Bistrian, A. H. Arnold, G. Ostroff, and R. A. Forse, "Effect of $\beta$-glucan from oats and yeast on serum lipids," Critical Reviews in Food Science and Nutrition, vol. 39, no. 2, pp. 189-202, 1999.

[11] V. A. Solah, B. O’Mara-Wallace, X. Meng et al., "Consumption of the soluble dietary fibre complex polyglycopleX ${ }^{\circledR}$ reduces glycaemia and increases satiety of a standard meal postprandially," Nutrients, vol. 8, no. 5, article no. 268, 2016.

[12] C. J. Rebello, Y.-F. Chu, W. D. Johnson et al., “The role of meal viscosity and oat $\beta$-glucan characteristics in human appetite control: A randomized crossover trial," Nutrition Journal, vol. 13, no. 1, article no. 49, 2014.

[13] AACC, "Approved methods of the american association of cereal chemists," in American Association of Cereal Chemists, Inc St Paul, Minnesota, USA, 2000.

[14] AOAC (The Association of Official Analytical Chemist), 2006, The official methods of analysis of AOAC international, 18th ed. The Assoc. Official Ana. Chem. Arlington, USA.

[15] M. C. Meilgaard, B. T. Carr, and G. V. Civille, Sensory evaluation techniques, CRC press, 2006.

[16] U. Bacha, M. Nasir, A. Khalique, and A. A. Anjum, "Sensory and physical attributes of sugar snaps cookies as a source of protein," Carpathian Journal of Food Science and Technology, vol. 5, no. 12, pp. 45-51, 2013.

[17] V. L. Singleton, R. Orthofer, and R. M. Lamuela-Raventós, "Analysis of total phenols and other oxidation substrates and antioxidants by means of folin-ciocalteu reagent," Methods in Enzymology, vol. 299, pp. 152-178, 1999.

[18] I. F. F. Benzie and J. J. Strain, "The ferric reducing ability of plasma (FRAP) as a measure of 'antioxidant power': the FRAP assay," Analytical Biochemistry, vol. 239, no. 1, pp. 70-76, 1996.

[19] P. Mladěnka, K. MacÁková, T. Filipský et al., "In vitro analysis of iron chelating activity of flavonoids," Journal of Inorganic Biochemistry, vol. 105, no. 5, pp. 693-701, 2011.

[20] S. R. Kirk and R. Sawyer, Pearson's Composition and Analysis of Foods, Addison Wesley Longman Ltd. Harlow, England, 9th edition, 1999.

[21] J. O. Uzuegbe and O. S. Eke, Course in food microbiology, pp 6070, Osprey publish centre, Owerri, Nigeria, 2001.

[22] K. Argyri, A. Athanasatou, M. Bouga, and M. Kapsokefalou, "The potential of an in vitro digestion method for predicting glycemic response of foods and meals," Nutrients, vol. 8, no. 4, article no. 42, 2016.

[23] R. L. Magaletta, S. N. DiCataldo, D. Liu, H. L. Li, R. P. Borwankar, and M. C. Martini, "In vitro method for predicting glycemic index of foods using simulated digestion and an artificial neural network," Cereal Chemistry, vol. 87, no. 4, pp. 363-369, 2010 
[24] M. Abu-Ghoush, T. J. Herald, F. Dowell, F. Xie, F. M. Aramouni, and R. Madl, "Effect of preservatives addition on the shelflife extensions and quality of flat bread as determined by near-infrared spectroscopy and texture analysis," International Journal of Food Science \& Technology, vol. 43, no. 2, pp. 357-364, 2008.

[25] K. Narayana and M. S. R. Narasinga, "Functional properties of raw and heat processed winged bean flour," Journal of Food Science, vol. 42, pp. 534-538, 1982.

[26] R. G. D. Steel, J. H. Torrie, and D. Dickey, Principles and Procedures of Statistics. A Biometrical Approach, McGraw Hills Book Co. Inc New York, 3rd edition, 1977.

[27] D. B. Duncan, "Multiple range and multiple F tests," Biometrics, vol. 11, pp. 1-42, 1955.

[28] A. A. Mohammed, E. M. Babiker, A. G. Khalid, N. A. Mohammed, and E. K. Khadir, "Nutritional evaluation and sensory characteristics of biscuits flour supplemented with difference levels of whey protein concentrates," International Journal of Food Processing Technology, 2016.

[29] G. Gizachew, B. Geremew, and A. Solomon, "Effect of cassava (manihot esculenta crantz) variety, drying method and blending ratio on the proximate composition and sensory properties of cassava-wheat composite bread," European Journal of Food Science and Technology, vol. 3, pp. 41-54, 2015.

[30] J. L. Sidel and H. Stone, "The role of sensory evaluation in the food industry," Food Quality and Preference, vol. 4, no. 1-2, pp. 65-73, 1993.

[31] S. Saeed, M. M. Ahmad, H. Kausar, S. Parveen, S. Masih, and A. Salam, "Effect of sweet potato flour on quality of cookies," Journal of Agriculture Research, vol. 50, pp. 525-536, 2012 (Chinese).

[32] A. Din, F. M. Anjum, T. Zahoor, and H. Nawaz, "Extraction and utilization of barley $\beta$-glucan for the preparation of functional beverage," International Journal of Agriculture and Biology, vol. 11, no. 6, pp. 737-740, 2009.

[33] D. A. J. M. Kerckhoffs, G. Hornstra, and R. P. Mensink, "Cholesterol-lowering effect of $\beta$-glucan from oat bran in mildly hypercholesterolemic subjects may decrease when $\beta$-glucan is incorporated into bread and cookies," American Journal of Clinical Nutrition, vol. 78, no. 2, pp. 221-227, 2003.

[34] M. Siwela, J. R. N. Taylor, and G. Duodu, "Phenolic content, antioxidant and sensory acceptability of wheat-finger millet composite cookies," Journal of Food Science and Technology, vol. 2, pp. 52-55, 2009.

[35] A. Lazaridou, A. Marinopoulou, N. P. Matsoukas, and C. G. Biliaderis, "Impact of flour particle size and autoclaving on $\beta$ glucan physicochemical properties and starch digestibility of barley rusks as assessed by in vitro assays," Bioactive Carbohydrates and Dietary Fibre, vol. 4, no. 1, pp. 58-73, 2014.

[36] F. Finocchiaro, B. Ferrari, A. Gianinetti et al., "Effects of barley $\beta$-glucan-enriched flour fractions on the glycaemic index of bread," International Journal of Food Sciences and Nutrition, vol. 63, no. 1, pp. 23-29, 2012.

[37] A. Cavallero, S. Empilli, F. Brighenti, and A. M. Stanca, "High (1 $\rightarrow 3,1 \rightarrow 4)$ - $\beta$-glucan barley fractions in bread making and their effects on human glycemic response," Journal of Cereal Science, vol. 36, no. 1, pp. 59-66, 2002.

[38] S. M. Tosh, Y. Brummer, T. M. S. Wolever, and P. J. Wood, "Glycemic response to oat bran muffins treated to vary molecular weight of $\beta$-glucan," Cereal Chemistry, vol. 85, no. 2, pp. 211-217, 2008.
[39] J. Gelroth and S. Ranhotra, "Food uses of fibre in," in Handbook of dietary fibre, SS. Cho and ML. Dreher, Eds., pp. 435-449, Marcel Dekker, New York, USA, 2001.

[40] P.-J. Tsai, T.-Y. Yu, S.-H. Chen, C.-C. Liu, and Y.-F. Sun, "Interactive role of color and antioxidant capacity in caramels," Food Research International, vol. 42, no. 3, pp. 380-386, 2009.

[41] M. Haghshenas, H. Hosseini, K. Nayebzadeh, B. S. Kakesh, M. Mahmoudzadeh, and R. K. Fonood, "Effect of beta glucan and carboxymethyl cellulose on lipid oxidation and fatty acid composition of pre-cooked shrimp nugget during storage," LWT- Food Science and Technology, vol. 62, no. 2, pp. 1192-1197, 2015.

[42] A. Shakerardekani, R. Karim, H. M. Ghazali, and N. L. Chin, "Textural, rheological and sensory properties and oxidative stability of nut spreads-a review," International Journal of Molecular Sciences, vol. 14, no. 2, pp. 4223-4241, 2013.

[43] J. P. Smith, D. P. Daifas, W. El-Khoury, J. Koukoutsis, and A. ElKhoury, "Shelf life and safety concerns of bakery products - A review," Critical Reviews in Food Science and Nutrition, vol. 44, no. 1, pp. 19-55, 2004.

[44] D. A. Mossel and P. Van Netten, "Microbiological reference values for foods: a European perspective," Association of Official Analytical Chemists, vol. 74, no. 2, pp. 420-432, 1990.

[45] T. L. Jeng, Y. C. Chiang, C. C. Lai et al., "Sweet potato leaf extract inhibits the simulated in vitro gastrointestinal digestion of native starch," Journal of Food and Drug Analysis, vol. 23, no. 3, pp. 399-406, 2015.

[46] G. E. Inglett, D. Chen, and S. Liu, "Physical properties of sugar cookies containing chia-oat composites," Journal of the Science of Food and Agriculture, vol. 94, no. 15, pp. 3226-3233, 2014.

[47] U. Kamboj, P. Guha, and S. Mishra, "Determination of chemical properties of desi chickpea flour (besan) using near infrared spectroscopy and chemometrics," International Journal Tropical Agriculture, vol. 33, pp. 3467-3470, 2015.

[48] M. Havrlentová, Z. Petruláková, A. Burgárová et al., "Properties of cereal $\beta$-D-glucan hydrocolloids and their effect on bread and ketchup parameters," Polish Journal of Food and Nutrition Sciences, vol. 63, no. 2, pp. 79-86, 2013.

[49] S. P. Cauvain, Technology of Breadmaking, Britain, pp. 285-286, Thomson Publishing, 2007.

[50] C. Balagopalan, G. Padmaja, S. K. Nanda, and S. N. Moorthy, Cassva in food, feed and industry, pp. 126-127, CRC Press, Boca Raton, FL, USA, 2010.

[51] S. Chandra, S. Singh, and D. Kumari, "Evaluation of functional properties of composite flours and sensorial attributes of composite flour biscuits," Journal of Food Science and Technology, vol. 52, no. 6, pp. 3681-3688, 2015. 

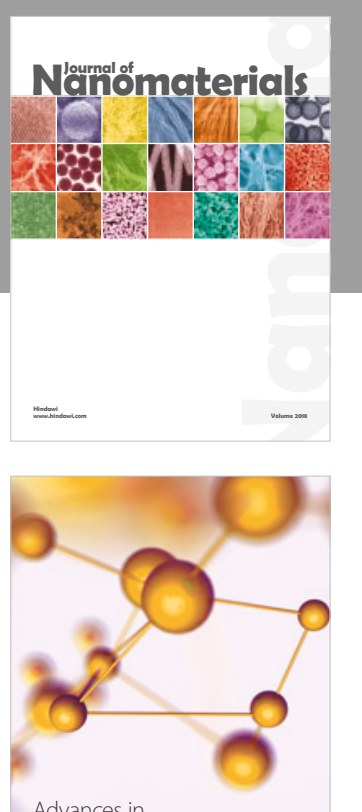

Physical Chemistry
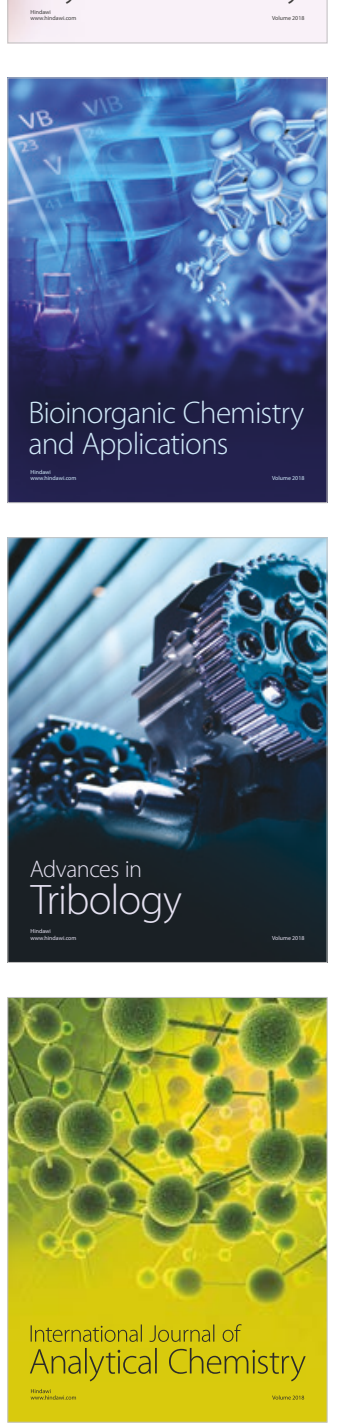

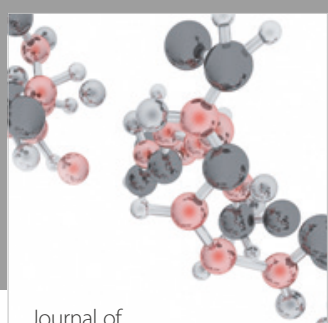

Analytical Methods

in Chemistry

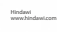

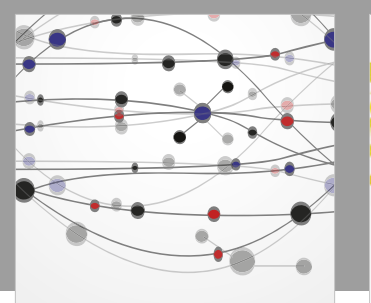

The Scientific World Journal

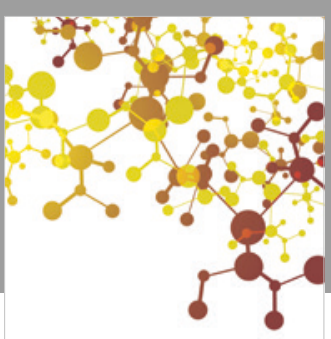

Journal of

Applied Chemistry
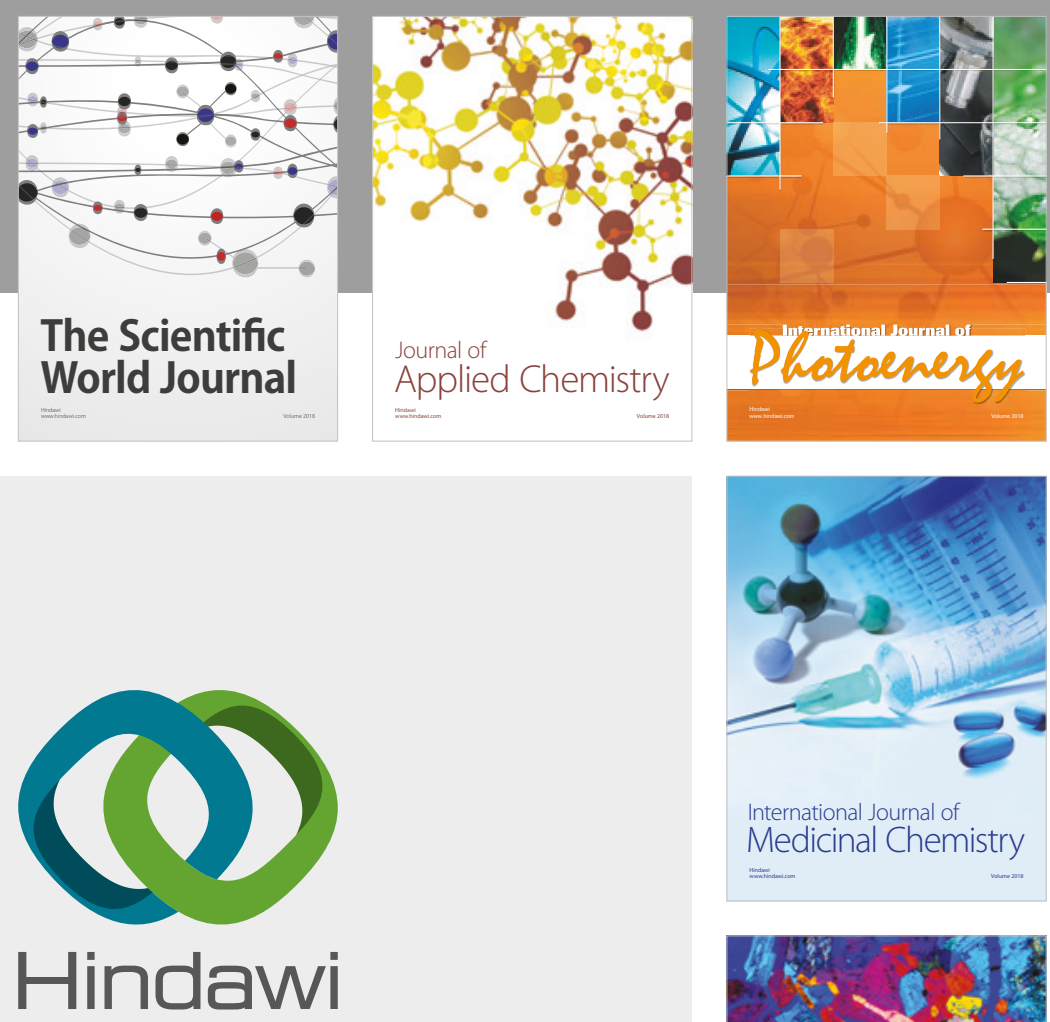

Submit your manuscripts at

www.hindawi.com
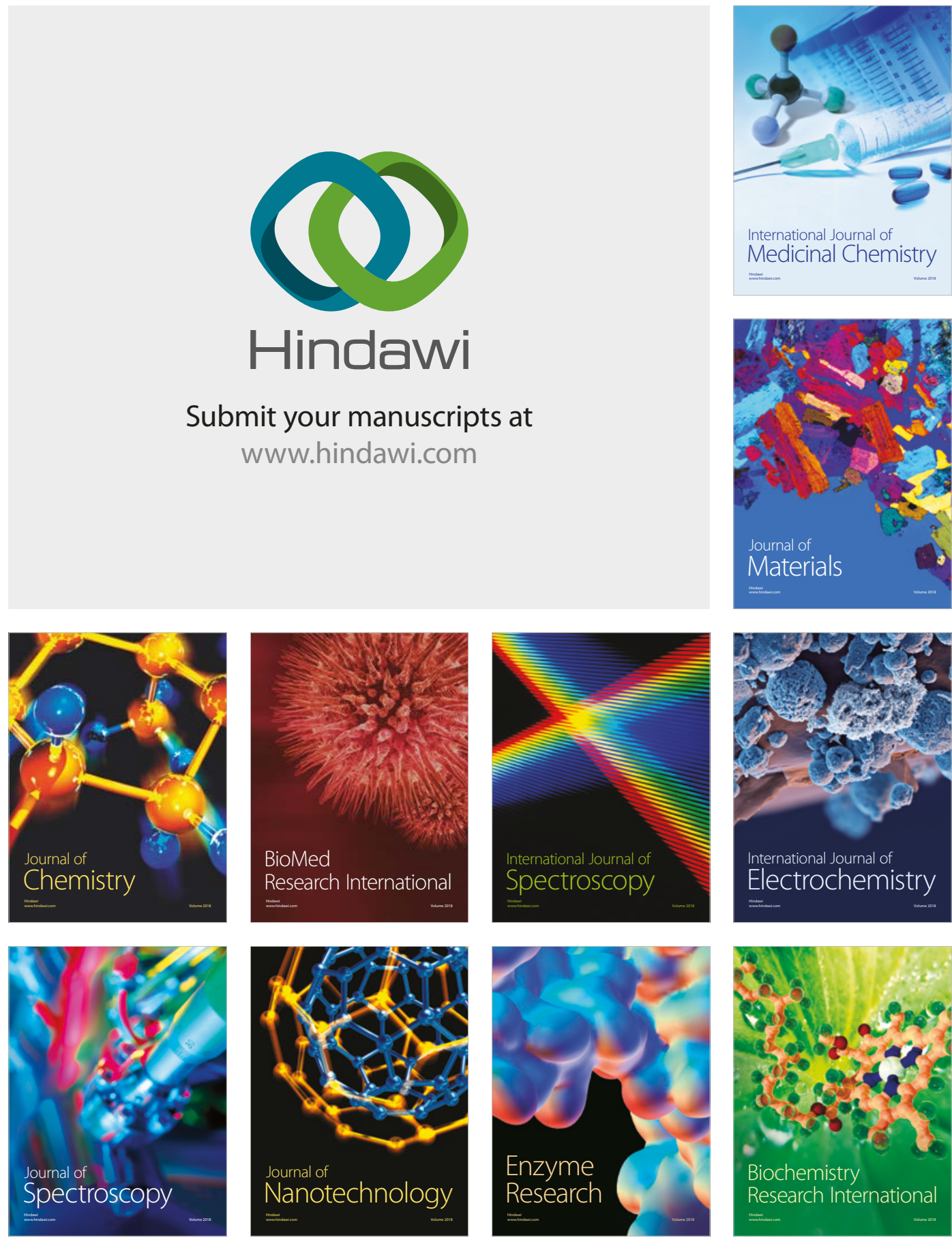
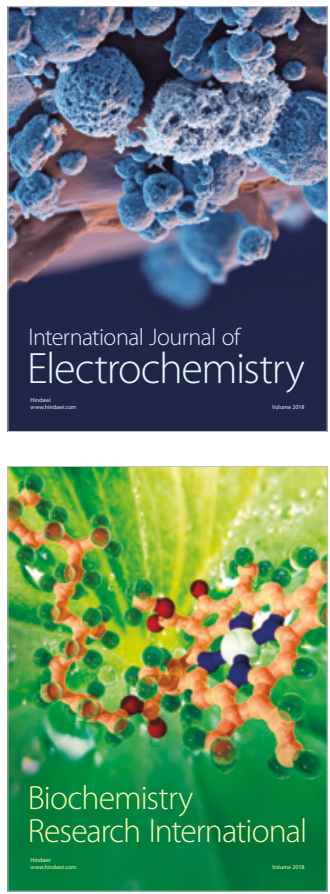